\title{
Living Ring-Opening Metathesis Polymerization of Exo-Norbornenes Bearing Both Cyano and Ester Functionalities by a Well-Defined Ruthenium Catalyst
}

\author{
Yasushi NishiHara, ${ }^{1, \dagger}$ Yoshiaki InOUE, ${ }^{1}$ Akira T. SAITO, ${ }^{1}$ \\ Yuushou NAKAYAMA, ${ }^{2}$ Takeshi SHIONO $^{2}$, and Kentaro TAKAGI ${ }^{1}$ \\ ${ }^{1}$ Department of Chemistry, Graduate School of Natural Science and Technology, Okayama University, \\ Tsushimanaka, Okayama 700-8530, Japan \\ ${ }^{2}$ Department of Applied Chemistry, Graduate School of Engineering, Hiroshima University, \\ Higashi-Hiroshima 739-8527, Japan
}

(Received October 10, 2006; Accepted December 29, 2006; Published February 26, 2007)

\begin{abstract}
Exo-ethyl 3-cyanobicyclo[2.2.1]hept-5-ene-2-carboxylate (A) and exo- ${ }^{n}$ butyl 3-cyanobicyclo[2.2.1]hept-5-ene-2-carboxylate $(\mathbf{B})$ bearing both cyano and ester groups were subjected to homopolymerization by ringopening metathesis polymerization with a well-defined $\mathrm{Ru}$ catalyst, $\left(\mathrm{H}_{2} \mathrm{IMes}\right)(3 \text {-bromopyridine })_{2} \mathrm{Cl}_{2} \mathrm{Ru}=\mathrm{CHPh}(3)$ $\left(\mathrm{H}_{2} \mathrm{IMes}=N, N^{\prime}\right.$-bis(mesityl)-4,5-dihydroimidazol-2-ylidine) at low temperature. The characterization of the synthesized homopolymers by GPC analyses showed a value of a number-average molecular weight $\left(M_{\mathrm{n}}\right)$ as high as 296,000 and a narrow polydispersity index $(<1.06)$. The results imply that the initiator 3 had a compatibility of the polar functional groups and promoted fairly well-defined living polymerization. The glass transition temperatures of the homopolymers obtained from monomer $\mathbf{A}$ were significantly higher than those observed for polymers from monomer $\mathbf{B}$ obtained under the same reaction conditions. The rates of homopolymerizations of monomer $\mathbf{A}, \mathbf{B}$, and the parent norbornene $(\mathbf{C})$ were determined by the monitoring the consumption of the monomers by the ${ }^{1} \mathrm{H}$ NMR spectra. It was revealed that the polymerization rate for the homopolymerization of monomer $\mathbf{A}$ was almost same as that of monomer $\mathbf{B}$, but much slower than that of $\mathbf{C}$. On the basis of the successful homopolymerization, the synthesis of block and random copolymers derived from monomers $\mathbf{A}, \mathbf{B}$, and $\mathbf{C}$ via living polymerization using catalyst $\mathbf{3}$ was also accomplished. [doi:10.1295/polymj.PJ2006129]

KEY WORDS Ring-Opening Metathesis Polymerization / Living Polymerization / N-Heterocyclic Carbene Ligands / Ruthenium / Copolymerization /
\end{abstract}

Over past decades, ring-opening metathesis polymerization (ROMP) has emerged as a mild, efficient method for the synthesis of well-defined and highly functionalized polymers. ${ }^{1-5}$ These advantages make ROMP an increasingly attractive method for the synthesis of polymers with exposed polar functional groups along the backbone. ${ }^{6}$ In particular, well-defined olefin-metathesis catalysts, such as ruthenium-alkylidene complexes of the type $\left(\mathrm{PCy}_{3}\right)_{2} \mathrm{Cl}_{2} \mathrm{Ru}=\mathrm{CHPh}$ $(\mathbf{1} ; \mathrm{Cy}=$ cyclohexyl, Figure 1, 1st generation Grubbs' Catalyst), ${ }^{2 b, 7-9}$ tolerate a remarkably wide array of polar functional groups ${ }^{10-12}$ in the monomer and solvent. ${ }^{13}$ These include acids, alcohols, aldehydes, esters, and amides. Further, a number of examples of living polymerizations leading to well-defined microstructures have been descrived. ${ }^{2 b, 2 e, 2 f, 3 b, 5 b, 8 a, 8 c, 11 a, 11 b, 12,14-17}$ However, this ruthenium compound $\mathbf{1}$ is limited by poor initiation properties in that polymers with moderate polydispersity indices (PDI) are formed and it is incompatible with basic functional groups, notably nitriles and amines. ${ }^{18,19}$ The recently developed $N$ heterocyclic carbene, 2nd generation Grubbs' Cata- lyst, $\left(\mathrm{H}_{2} \mathrm{IMes}\right)\left(\mathrm{PCy}_{3}\right) \mathrm{Cl}_{2} \mathrm{Ru}=\mathrm{CHPh}\left(2\right.$, Figure 1) ${ }^{20,21}$ $\left(\mathrm{H}_{2} \mathrm{IMes}=N, N\right.$-bis(mesityl)-4,5-dihydroimidazol-2ylidene) exhibits comparable activity but also functional group tolerance. Recently, it was established that substituents such as chloro, fluoro, cyano, esters
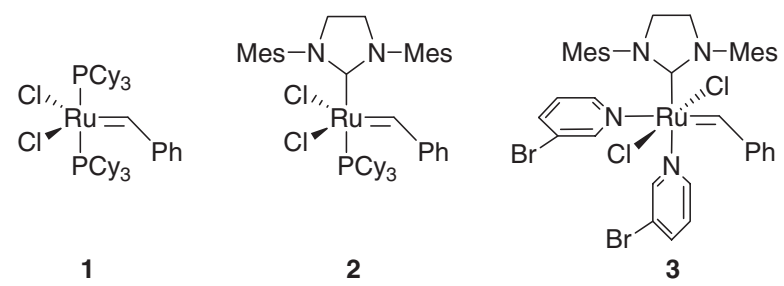

$\left(\right.$ Mes $\left.=2,4,6-\mathrm{Me}_{3} \mathrm{C}_{6} \mathrm{H}_{2}\right)$
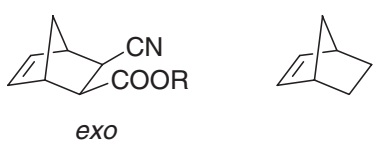

$A: R=E t$

B: $\mathrm{R}={ }^{n} \mathrm{Bu}$

C

Figure 1. Initiators $\mathbf{1}, \mathbf{2}$, and $\mathbf{3}$ and monomers $\mathbf{A}, \mathbf{B}$, and $\mathbf{C}$.

${ }^{\dagger}$ To whom correspondence should be addressed (Tel/Fax: +81-86-251-7855, E-mail: ynishiha@cc.okayama-u.ac.jp). 
plus other hetero-atom groups, ${ }^{22}$ as well as nitriles, amines, sulfides and phosphines ${ }^{13 a, 19 e, 23}$ as functionalities can be tolerated in ROMP. Nevertheless, ruthenium complex 2 generally gives polymers with uncontrolled molecular weights and broad PDIs, due to fast propagation rates and slow initiation rates (low $k_{\mathrm{i}} / k_{\mathrm{p}}$; $k_{\mathrm{i}}=$ the rate constant for initiation, $k_{\mathrm{p}}=$ the rate constant for propagation $)^{2 \mathrm{e}, 24}$ and competing chain-transfer reactions. ${ }^{2 \mathrm{~d}, 25}$

On the other hand, the ruthenium-initiated ROMP of strained cyclic olefins, most notably norbornenes, has been often employed to prepare highly defined homo- and copolymers bearing a broad variety of functionalities ${ }^{26,27}$ Recently we reported that the palladium-catalyzed cyanoesterification of norbornadienes leads to stereoselective formation of doubly functionalized exo-norbornenes $\mathbf{A}$ and $\mathbf{B}$ bearing both cyano and ester groups $\left(\mathrm{R}=\mathrm{Et}\right.$ and $\left.{ }^{n} \mathrm{Bu}\right){ }^{28} \mathrm{We}$ also reported that monomer $\mathbf{A}$ was found to be inefficient for the living ROMP using $2 .{ }^{29}$

Grubbs recently reported that cyclooctene and norbornenes containing esters, cyano, and acetate can be polymerized by $\left(\mathrm{H}_{2} \mathrm{IMes}\right.$ )(3-bromopyridine) ${ }_{2} \mathrm{Cl}_{2} \mathrm{Ru}=$ $\mathrm{CHPh}$ (3, Figure 1). This initiator has a higher initiation rate and produces polymers with narrow polydispersities in a living manner. ${ }^{13 a, 30,31}$ This encouraged us to exploit the living polymerization of poly(norbornene)s containing a high proportion of cyano and ester substituents with a view of potential application to the improvement of the thermal stabilities of optoelectronic materials. The work reported herein demonstrates ring-opening metathesis polymerization generates homopolymers and copolymers from a variety of doubly functionalized norbornene derivatives in a living manner using $\mathbf{3}$ as an initiator.

\section{EXPERIMENTAL}

\section{General}

All the reactions were carried out under an Ar atmosphere using standard Schlenk techniques. Glassware was dried in an oven $\left(130^{\circ} \mathrm{C}\right)$ and heated under reduced pressure before use. For thin layer chromatography (TLC) analyses throughout this work, Merck precoated TLC plates (silica gel $60 \mathrm{GF}_{254}, 0.25 \mathrm{~mm}$ ) were used. Silica gel column chromatography was carried out using Silica gel $60 \mathrm{~N}$ (spherical, neutral, 40-100 $\mu \mathrm{m}$ ) from Kanto Chemicals Co., Ltd.

\section{Materials}

Ethyl cyanoformate, norbornene, and norbornadiene were purchased from Aldrich and used as received. ${ }^{n}$ Butyl cyanoformate, ${ }^{32}$ exo-ethyl 3-cyanobicyclo[2.2.1]hept-5-ene-2-carboxylate (A), exo- ${ }^{n}$ butyl 3-cyanobicyclo[2.2.1] hept-5-ene-2-carboxylate $(\mathbf{B}),{ }^{28}$ and a ruthenium catalyst $3^{30 a}$ were prepared according to the literature procedures. $\mathrm{CH}_{2} \mathrm{Cl}_{2}$ was dried over activated molecular sieves and stored in a Schlenk tube after three freeze-pump-thaw cycles were performed.

\section{Measurements}

${ }^{1} \mathrm{H}$ and ${ }^{13} \mathrm{C}$ NMR spectra were recorded on Varian INOVA $600(600 \mathrm{MHz})$ or Mercury $300(300 \mathrm{MHz})$ spectrometers at an ambient temperature with the chemical shifts being expressed in parts per million based on residual $\mathrm{CHCl}_{3}$ and $\mathrm{CDHCl}_{2}$ as internal standards. Infrared spectra were recorded on a Shimadzu IRPrestige-21 spectrophotometer. Gel permeation chromatography (GPC) analyses were carried out with JASCO HPLC system equipped with an RI detector using THF as an eluent at a flow rate of 1.0 $\mathrm{mL} / \mathrm{min}$, with a Tosoh MultiporeHXL-M column. Molecular weights and molecular weight distributions were estimated on the basis of the calibration curve obtained by polystyrene standards. The glass transition temperature $\left(T_{\mathrm{g}}\right)$ of the polymers were measured by a differential scanning calorimetry (DSC) using a Seiko SSC 5100 DSC 22C apparatus. The heating rate was $10^{\circ} \mathrm{C} / \mathrm{min}$ in a nitrogen stream. The $T_{\mathrm{g}}$ value was determined in the second heating. The thermodegradation behavior was measured by differential thermal analysis using a Seiko TG/DTA6300 apparatus. Elemental analyses were carried out with a PerkinElmer $2400 \mathrm{CHN}$ elemental analyzer at Osaka City University.

Representative Procedure for Living Homopolymerization of Monomer $\boldsymbol{A}(R=E t)$ at $-15^{\circ} \mathrm{C}$

To a solution of monomer $\mathbf{A}\left(4.2 \times 10^{-2} \mathrm{~mL}, 0.24\right.$ $\mathrm{mmol})$ in dichloromethane $(0.75 \mathrm{~mL})$ was added initiator $3\left(2.9 \times 10^{-3} \mathrm{M}\right.$ stock solution in $\mathrm{CH}_{2} \mathrm{Cl}_{2}$, $\left.0.25 \mathrm{~mL}, 0.72 \times 10^{-3} \mathrm{mmol}, 0.3 \mathrm{~mol} \%\right)$ at $-15^{\circ} \mathrm{C}$. The reaction mixture was stirred for $12 \mathrm{~h}$ at $-15^{\circ} \mathrm{C}$, quenched with ethyl vinyl ether $\left(1.4 \times 10^{-2} \mathrm{~mL}\right.$, $0.14 \mathrm{mmol}$ ), and stirred for $10 \mathrm{~min}$ at $-15^{\circ} \mathrm{C}$. After reprecipitation from $\mathrm{CH}_{2} \mathrm{Cl}_{2}(1 \mathrm{~mL}) / \mathrm{MeOH}(100 \mathrm{~mL})$ with vigorous stirring, the formed polymer $\mathbf{A}$ was filtrated and dried under reduced pressure at room temperature for $12 \mathrm{~h}$ to give off-white solid in $85 \%$ yield $(39 \mathrm{mg}, 0.20 \mathrm{mmol})$. FT-IR $\left(\mathrm{CH}_{2} \mathrm{Cl}_{2}, \mathrm{~cm}^{-1}\right)$ :

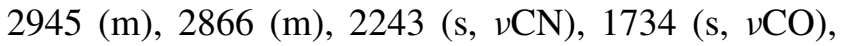
1457 (m), 1413 (m), 1376 (s), 1187 (w), 1098 (w), $1017(\mathrm{w}), 899(\mathrm{~m}), 861(\mathrm{~s}), 803(\mathrm{~m}) .{ }^{1} \mathrm{H} \mathrm{NMR}\left(\mathrm{CDCl}_{3}\right.$, $300 \mathrm{MHz}, \mathrm{rt}$ ): $\delta 1.19-1.41$ (bs, $4 \mathrm{H}, \mathrm{CH}_{3}+$ cyclopentane), 2.01-2.38 (bs, 1H, cyclopentane), 2.78-3.21 (partially collapsed bs, 3H, cyclopentane), 3.21-3.58 (bs, $1 \mathrm{H}$, cyclopentane), 4.18-4.40 (partially collapsed bs, $2 \mathrm{H}, \mathrm{OCH}_{2}$ ), 5.20-5.30 (bs, $=\mathrm{CH}_{c i s}$ ), 5.30-5.50 (partially collapsed bs, $=\mathrm{CH}_{\text {cis and trans }}$ ), $5.50-5.65$ 
(bs, $\left.=\mathrm{CH}_{\text {trans }}\right) ;{ }^{13} \mathrm{C}\left\{{ }^{1} \mathrm{H}\right\} \mathrm{NMR}\left(\mathrm{CDCl}_{3}, 75 \mathrm{MHz}, \mathrm{rt}\right): \delta$ 14.1-14.2 $\left(\mathrm{CH}_{2} \mathrm{CH}_{3}\right), 37.8-39.0$ (cyclopentane), 39.541.4 (cyclopentane), 42.4-45.8 (cyclopentane), 47.248.0 (cyclopentane), 51.0-52.5 (cyclopentane), 61.5$62.1\left(\mathrm{OCH}_{2}\right), 118.4-119.0(\mathrm{CN}), 130.0-134.2(=\mathrm{CH})$, 170.5-171.5 (COO). Anal. Calcd for $\mathrm{C}_{11} \mathrm{H}_{13} \mathrm{NO}_{2}$ : C, 69.09; H, 6.85; N, 7.32\%. Found: C, 67.96; H, 6.78; $\mathrm{N}, 6.79 \%$.

\section{Homopolymer $\boldsymbol{B}\left(R={ }^{n} \mathrm{Bu}\right)$}

To a solution of monomer $\mathbf{B}\left(4.9 \times 10^{-2} \mathrm{~mL}\right.$, $0.24 \mathrm{mmol})$ in dichloromethane $(0.75 \mathrm{~mL})$ was added initiator $3\left(2.9 \times 10^{-3} \mathrm{M}\right.$ stock solution in $\mathrm{CH}_{2} \mathrm{Cl}_{2}$, $0.25 \mathrm{~mL}, 0.72 \times 10^{-3} \mathrm{mmol}, 0.3 \mathrm{~mol} \%$ ) at $-15^{\circ} \mathrm{C}$. The reaction mixture was stirred for $12 \mathrm{~h}$ at $-15^{\circ} \mathrm{C}$, quenched with ethyl vinyl ether $\left(1.4 \times 10^{-2} \mathrm{~mL}\right.$, $0.14 \mathrm{mmol}$ ), and stirred for $10 \mathrm{~min}$ at $-15^{\circ} \mathrm{C}$. After reprecipitation from $\mathrm{CH}_{2} \mathrm{Cl}_{2}(1 \mathrm{~mL}) / \mathrm{MeOH}(100 \mathrm{~mL})$ with vigorous stirring, the formed polymer $\mathbf{B}$ was filtrated and dried under reduced pressure at room temperature for $12 \mathrm{~h}$ to give off-white solid in $70 \%$ yield $(37 \mathrm{mg}, 0.169 \mathrm{mmol})$. FT-IR $\left(\mathrm{CH}_{2} \mathrm{Cl}_{2}, \mathrm{~cm}^{-1}\right)$ : 3078 (s), 2964 (s), 2935 (s), 2875 (s), 2243 (s, vCN), 1733 (s, vCO), 1363 (s), 1295 (s), 1236 (s), 1184 (w), 969 (s), 890 (m),786 (m). ${ }^{1} \mathrm{H}$ NMR $\left(\mathrm{CDCl}_{3}, 300 \mathrm{MHz}\right.$, rt): $\delta$ 0.81-1.01 (bs, $3 \mathrm{H}, \mathrm{CH}_{2} \mathrm{CH}_{2} \mathrm{CH}_{2} \mathrm{CH}_{3}$ ), 1.15-1.45 (bs, $3 \mathrm{H}$, cyclopentane $+\mathrm{CH}_{2} \mathrm{CH}_{2} \mathrm{CH}_{2} \mathrm{CH}_{3}$ ), 1.551.79 (bs, $2 \mathrm{H}, \mathrm{CH}_{2} \mathrm{CH}_{2} \mathrm{CH}_{2} \mathrm{CH}_{3}$ ) 2.00-2.40 (bs, $1 \mathrm{H}$, cyclopentane), 2.70-3.25 (bs, $3 \mathrm{H}$, cyclopentane), 3.25-3.60 (bs, $1 \mathrm{H}$, cyclopentane), 4.05-4.30 (bs, $2 \mathrm{H}$, $\left.\mathrm{OCH}_{2}\right), 5.18-5.33\left(\mathrm{bs}, 1 \mathrm{H},=\mathrm{CH}_{c i s}\right), 5.33-5.50(\mathrm{bm}$, $\left.1 \mathrm{H},=\mathrm{CH}_{\text {cis and trans }}\right), 5.50-5.65$ (bs, $\left.1 \mathrm{H},=\mathrm{CH}_{\text {trans }}\right)$; ${ }^{13} \mathrm{C}\left\{{ }^{1} \mathrm{H}\right\}$ NMR $\left(\mathrm{CDCl}_{3}, 150 \mathrm{MHz}, \mathrm{rt}\right): \delta 13.6-13.7$ $\left(\mathrm{CH}_{2} \mathrm{CH}_{2} \mathrm{CH}_{2} \mathrm{CH}_{3}\right), \quad 19.0-19.1 \quad\left(\mathrm{CH}_{2} \mathrm{CH}_{2} \mathrm{CH}_{2} \mathrm{CH}_{3}\right)$, 30.4-30.5 $\left(\mathrm{CH}_{2} \mathrm{CH}_{2} \mathrm{CH}_{2} \mathrm{CH}_{3}\right), 37.8-38.6$ (cyclopentane), 39.7-40.9 (cyclopentane), 42.6-45.6 (cyclopentane), 47.2-48.1 (cyclopentane), 51.4-52.4 (cyclopentane), 65.5-65.8 $\left(\mathrm{OCH}_{2}\right), 118.4-118.8(\mathrm{CN}), 130.4-$ $133.9(=C \mathrm{H}), 170.8-171.4(\mathrm{COO})$. Anal. Calcd for $\mathrm{C}_{13} \mathrm{H}_{17} \mathrm{NO}_{2}$ : C, 71.21; H, 7.81; N, 6.39\%. Found: $\mathrm{C}$, $70.25 ; \mathrm{H}, 7.78 ; \mathrm{N}, 6.30 \%$.

\section{Homopolymer $\boldsymbol{C}$}

To a solution of monomer $\mathbf{C}(22.6 \mathrm{mg}, 0.24 \mathrm{mmol})$ in dichloromethane $(0.75 \mathrm{~mL})$ was added initiator $\mathbf{3}$ $\left(2.9 \times 10^{-3} \mathrm{M}\right.$ stock solution in $\mathrm{CH}_{2} \mathrm{Cl}_{2}, 0.25 \mathrm{~mL}$, $\left.0.72 \times 10^{-3} \mathrm{mmol}, 0.3 \mathrm{~mol} \%\right)$ at $-15^{\circ} \mathrm{C}$. The reaction mixture was stirred for $12 \mathrm{~h}$ at $-15^{\circ} \mathrm{C}$, quenched with ethyl vinyl ether $\left(1.4 \times 10^{-2} \mathrm{~mL}\right)$, and stirred for $10 \mathrm{~min}$ at $-15^{\circ} \mathrm{C}$. After reprecipitation from $\mathrm{CH}_{2} \mathrm{Cl}_{2}$ $(1 \mathrm{~mL}) / \mathrm{MeOH}(100 \mathrm{~mL})$ with vigorous stirring, the formed polymer $\mathbf{C}$ was filtrated and dried under reduced pressure at room temperature for $12 \mathrm{~h}$ to give white solid in $58 \%$ yield $(12.9 \mathrm{mg}, 0.14 \mathrm{mmol})$. FT-IR $\left(\mathrm{CH}_{2} \mathrm{Cl}_{2}, \mathrm{~cm}^{-1}\right)$ : 3688 (s), 3600 (s), 2946 (s), 2866 (s),
1606 (s). ${ }^{1} \mathrm{H}$ NMR $\left(\mathrm{CDCl}_{3}, 300 \mathrm{MHz}, \mathrm{rt}\right): \delta 0.95-1.10$ (bs, $1 \mathrm{H}$, cyclopentane), 1.21-1.41 (bs, $2 \mathrm{H}$, cyclopentane), 1.70-1.98 (bs, 3H, cyclopentane), 2.38-2.51 (bs, 1H, cyclopentane), 2.70-2.90 (bs, $1 \mathrm{H}$, cyclopentane), 5.18-5.24 (bd, $1.55 \mathrm{H},=\mathrm{CH}_{\text {cis }}$ ), 5.31-5.37 (bm, $\left.1 \mathrm{H},=\mathrm{CH}_{\text {trans }}\right) ;{ }^{13} \mathrm{C}\left\{{ }^{1} \mathrm{H}\right\} \mathrm{NMR}\left(\mathrm{CDCl}_{3}, 150 \mathrm{MHz}, \mathrm{rt}\right)$ : \& 32.2-33.1 (cyclopentane), 38.4-38.6 (cyclopentane), 41.4-43.4 (cyclopentane), 132.8-134.0 (=CH).

The ${ }^{1} H$ NMR Monitoring for Observation of Active Species during Homopolymerization of Monomer $\boldsymbol{A}$

To a $\mathrm{CD}_{2} \mathrm{Cl}_{2}(0.50 \mathrm{~mL})$ solution of initiator $3(2.5 \times$ $10^{-2} \mathrm{M}$ solution in $\mathrm{CD}_{2} \mathrm{Cl}_{2}, 0.40 \mathrm{~mL}, 0.01 \mathrm{mmol}, 10$ mol \%) in an NMR tube was added monomer $\mathbf{A}$ (1.0 M solution in $\mathrm{CD}_{2} \mathrm{Cl}_{2}, 0.1 \mathrm{~mL}, 0.1 \mathrm{mmol}$ ) at room temperature. The ${ }^{1} \mathrm{H}$ NMR spectra $(300 \mathrm{MHz})$ were recorded after $1 \mathrm{~min}$ and $30 \mathrm{~min}$. Then, the ${ }^{1} \mathrm{H}$ NMR spectra $(300 \mathrm{MHz})$ were recorded $1 \mathrm{~min}$ after addition of ethyl vinyl ether $\left(2.0 \times 10^{-2} \mathrm{~mL}, 0.2 \mathrm{mmol}\right)$.

Kinetic Studies on Homopolymerization of Monomer $\boldsymbol{A}$

To a $\mathrm{CD}_{2} \mathrm{Cl}_{2}(0.50 \mathrm{~mL})$ solution of initiator $3(1.9 \times$ $10^{-2} \mathrm{M}$ stock solution in $\mathrm{CD}_{2} \mathrm{Cl}_{2}, 2.0 \times 10^{-2} \mathrm{~mL}$, $\left.3.8 \times 10^{-4} \mathrm{mmol}, 0.3 \mathrm{~mol} \%\right)$ in an NMR tube was added monomer $\mathbf{A}\left(1.25 \mathrm{M}\right.$ solution in $\mathrm{CD}_{2} \mathrm{Cl}_{2}, 0.1$ $\mathrm{mL}, 0.125 \mathrm{mmol}$ ) at room temperature. The ${ }^{1} \mathrm{H}$ NMR spectra $(300 \mathrm{MHz})$ were recorded every $3 \mathrm{~min}$ over $30 \mathrm{~min}$. The residual amounts of monomer $\mathbf{A}$ were monitored using mesitylene $\left(0.1 \mathrm{M}\right.$ solution in $\mathrm{CD}_{2}$ $\mathrm{Cl}_{2}, 0.1 \mathrm{~mL}, 1.0 \times 10^{-2} \mathrm{mmol}$ ) as an internal standard.

\section{Kinetic Studies on Homopolymerization of Mono- mer $\boldsymbol{B}$}

To a $\mathrm{CD}_{2} \mathrm{Cl}_{2}(0.50 \mathrm{~mL})$ solution of initiator $3(1.9 \times$ $10^{-2} \mathrm{M}$ stock solution in $\mathrm{CD}_{2} \mathrm{Cl}_{2}, 2.0 \times 10^{-2} \mathrm{~mL}$, $\left.3.8 \times 10^{-4} \mathrm{mmol}, 0.3 \mathrm{~mol} \%\right)$ in an NMR tube was added monomer $\mathbf{B}\left(1.25 \mathrm{M}\right.$ solution in $\mathrm{CD}_{2} \mathrm{Cl}_{2}, 0.1$ $\mathrm{mL}, 0.125 \mathrm{mmol}$ ) at room temperature. The ${ }^{1} \mathrm{H}$ NMR spectra $(300 \mathrm{MHz})$ were recorded every $3 \mathrm{~min}$ over $30 \mathrm{~min}$. The residual amounts of monomer $\mathbf{B}$ were monitored using mesitylene $\left(0.1 \mathrm{M}\right.$ solution in $\mathrm{CD}_{2}$ $\mathrm{Cl}_{2}, 0.1 \mathrm{~mL}, 1.0 \times 10^{-2} \mathrm{mmol}$ ) as an internal standard.

\section{Synthesis of Diblock Copolymer $\boldsymbol{A B}$ at $-15^{\circ} \mathrm{C}$}

To a solution of monomer $\mathbf{A}\left(4.2 \times 10^{-2} \mathrm{~mL}, 0.24\right.$ $\mathrm{mmol})$ in dichloromethane $(1.75 \mathrm{~mL})$ was added initiator $3\left(9.5 \times 10^{-3} \mathrm{M}\right.$ solution in $\mathrm{CH}_{2} \mathrm{Cl}_{2}, 0.25 \mathrm{~mL}$, $2.4 \times 10^{-3} \mathrm{mmol}, 1.0 \mathrm{~mol} \%$ ) at $-15^{\circ} \mathrm{C}$. The reaction mixture was stirred for $6 \mathrm{~h}$ at $-15^{\circ} \mathrm{C}$. Then, monomer B $\left(4.9 \times 10^{-2} \mathrm{~mL}, 0.24 \mathrm{mmol}\right)$ was added to the reaction mixture. The reaction mixture was stirred for additional $6 \mathrm{~h}$ at $-15^{\circ} \mathrm{C}$, and quenched with ethyl vinyl ether $\left(1.4 \times 10^{-2} \mathrm{~mL}, 0.14 \mathrm{mmol}\right)$. The reaction mixture was stirred for $10 \mathrm{~min}$, and then warmed to room temperature. After reprecipitation from $\mathrm{CH}_{2} \mathrm{Cl}_{2}$ 
$(2 \mathrm{~mL}) / \mathrm{MeOH}(100 \mathrm{~mL})$, the formed polymer was dried under reduced pressure to give a diblock copolymer AB as pale yellow solid in $83 \%$ yield $(82 \mathrm{mg})$. $M_{\mathrm{n}}=75,000, M_{\mathrm{w}} / M_{\mathrm{n}}=1.03$. Cis content was $58 \%$. Anal. Calcd for $\left(\mathrm{C}_{11} \mathrm{H}_{13} \mathrm{NO}_{2}\right)_{0.5}\left(\mathrm{C}_{13} \mathrm{H}_{17} \mathrm{NO}_{2}\right)_{0.5}: \mathrm{C}$, 70.22; H, 7.37; N, 6.82\%. Found: C, 69.63; H, 7.31; $\mathrm{N}, 6.61 \%$.

\section{Synthesis of Diblock Copolymer BA at $-15^{\circ} \mathrm{C}$}

To a solution of monomer $\mathbf{B}\left(4.9 \times 10^{-2} \mathrm{~mL}, 0.24\right.$ $\mathrm{mmol})$ in dichloromethane $(1.75 \mathrm{~mL})$ was added initiator $3\left(9.5 \times 10^{-3} \mathrm{M}\right.$ solution in $\mathrm{CH}_{2} \mathrm{Cl}_{2}, 0.25 \mathrm{~mL}$, $2.4 \times 10^{-3} \mathrm{mmol}, 1.0 \mathrm{~mol} \%$ ) at $-15^{\circ} \mathrm{C}$. The reaction mixture was stirred for $6 \mathrm{~h}$ at $-15^{\circ} \mathrm{C}$. Then, monomer A $\left(4.2 \times 10^{-2} \mathrm{~mL}, 0.24 \mathrm{mmol}\right)$ was added to the reaction mixture. The reaction mixture was stirred for additional $6 \mathrm{~h}$ at $-15^{\circ} \mathrm{C}$, and quenched with ethyl vinyl ether $\left(1.4 \times 10^{-2} \mathrm{~mL}, 0.14 \mathrm{mmol}\right)$. The reaction mixture was stirred $10 \mathrm{~min}$, and then warmed to room temperature. After reprecipitation from $\mathrm{CH}_{2} \mathrm{Cl}_{2}$ $(2 \mathrm{~mL}) / \mathrm{MeOH}(100 \mathrm{~mL})$, the formed polymer was dried under reduced pressure to give a diblock copolymer BA as pale yellow solid in $82 \%$ yield $(81 \mathrm{mg})$. $M_{\mathrm{n}}=71,000, M_{\mathrm{w}} / M_{\mathrm{n}}=1.03$. Cis content was $58 \%$. Anal. Calcd for $\left(\mathrm{C}_{13} \mathrm{H}_{17} \mathrm{NO}_{2}\right)_{0.5}\left(\mathrm{C}_{11} \mathrm{H}_{13} \mathrm{NO}_{2}\right)_{0.5}$ : C, 70.22; H, 7.37; N, 6.82\%. Found: C, 69.64; H, 7.32; $\mathrm{N}, 6.70 \%$.

\section{Synthesis of Random Copolymer $\boldsymbol{A}+\boldsymbol{B}$ at $-15^{\circ} \mathrm{C}$}

To a mixture of monomer $\mathbf{A}\left(4.2 \times 10^{-2} \mathrm{~mL}, 0.24\right.$ $\mathrm{mmol})$ and monomer $\mathbf{B}\left(4.9 \times 10^{-2} \mathrm{~mL}, 0.24 \mathrm{mmol}\right)$ in dichloromethane $(1.5 \mathrm{~mL})$ was added initiator 3 $\left(1.45 \times 10^{-3} \mathrm{M}\right.$ solution in $\mathrm{CH}_{2} \mathrm{Cl}_{2}, 0.5 \mathrm{~mL}, 0.72 \times$ $10^{-3} \mathrm{mmol}$ ) at $-15^{\circ} \mathrm{C}$. The reaction mixture was stirred for $12 \mathrm{~h}$ at $-15^{\circ} \mathrm{C}$ and quenched with ethyl vinyl ether $\left(1.4 \times 10^{-2} \mathrm{~mL}, 0.14 \mathrm{mmol}\right)$. The reaction mixture was stirred for $10 \mathrm{~min}$, and then warmed to room temperature. Reprecipitation from $\mathrm{CH}_{2} \mathrm{Cl}_{2}(2 \mathrm{~mL}) /$ $\mathrm{MeOH}(100 \mathrm{~mL})$ and drying under reduced pressure afforded random copolymer $\mathbf{A}+\mathbf{B}$ in $87 \%$ yield $(83 \mathrm{mg})$ as white solid. $M_{\mathrm{n}}=190,000, M_{\mathrm{w}} / M_{\mathrm{n}}=$ 1.09. Cis content was $59 \%$. Anal. Calcd for $\left(\mathrm{C}_{11} \mathrm{H}_{13}-\right.$ $\left.\mathrm{NO}_{2}\right)_{0.5}\left(\mathrm{C}_{13} \mathrm{H}_{17} \mathrm{NO}_{2}\right)_{0.5}: \mathrm{C}, 70.22 ; \mathrm{H}, 7.37 ; \mathrm{N}, 6.82 \%$. Found: $\mathrm{C}, 69.48 ; \mathrm{H}, 7.19 ; \mathrm{N}, 6.72 \%$.

\section{Synthesis of Diblock Copolymer BC at $-15^{\circ} \mathrm{C}$}

To a solution of monomer $\mathbf{B}\left(4.9 \times 10^{-2} \mathrm{~mL}, 0.24\right.$ $\mathrm{mmol})$ in dichloromethane $(1.75 \mathrm{~mL})$ was added initiator $3\left(2.9 \times 10^{-3} \mathrm{M}\right.$ stock solution in $\mathrm{CH}_{2} \mathrm{Cl}_{2}$, $0.25 \mathrm{~mL}, 0.72 \times 10^{-3} \mathrm{mmol}, 0.3 \mathrm{~mol} \%$ ) at $-15^{\circ} \mathrm{C}$. The reaction mixture was stirred for $12 \mathrm{~h}$ at $-15^{\circ} \mathrm{C}$. Then, monomer $\mathbf{C}(23 \mathrm{mg}, 0.24 \mathrm{mmol})$ was added to the reaction mixture. The reaction mixture was stirred for additional $12 \mathrm{~h}$ at $-15^{\circ} \mathrm{C}$ and quenched with ethyl vinyl ether $\left(1.4 \times 10^{-2} \mathrm{~mL}, 0.14 \mathrm{mmol}\right)$. The reaction mixture was stirred for $10 \mathrm{~min}$, and then warmed to room temperature. After reprecipitation from $\mathrm{CH}_{2} \mathrm{Cl}_{2}$ $(2 \mathrm{~mL}) / \mathrm{MeOH}(100 \mathrm{~mL})$, the formed polymer was dried under reduced pressure to give a diblock copolymer BC as white solid in $69 \%$ yield $(52 \mathrm{mg})$. $M_{\mathrm{n}}=247,000 . M_{\mathrm{w}} / M_{\mathrm{n}}=1.03$.

\section{Synthesis of Diblock Copolymer $\boldsymbol{C B}$ at $-15^{\circ} \mathrm{C}$}

To a solution of monomer $\mathbf{C}(23 \mathrm{mg}, 0.24 \mathrm{mmol})$ in dichloromethane $(1.75 \mathrm{~mL})$ was added initiator $\mathbf{3}$ $\left(2.9 \times 10^{-3} \mathrm{M}\right.$ stock solution in $\mathrm{CH}_{2} \mathrm{Cl}_{2}, 0.25 \mathrm{~mL}$, $\left.0.72 \times 10^{-3} \mathrm{mmol}, 0.3 \mathrm{~mol} \%\right)$ at $-15^{\circ} \mathrm{C}$. The reaction mixture was stirred for $12 \mathrm{~h}$ at $-15^{\circ} \mathrm{C}$. Then, monomer $\mathbf{B}\left(4.9 \times 10^{-2} \mathrm{~mL}, 0.24 \mathrm{mmol}\right)$ was added to the reaction mixture. The reaction mixture was stirred for additional $12 \mathrm{~h}$ at $-15^{\circ} \mathrm{C}$ and quenched with ethyl vinyl ether $\left(1.4 \times 10^{-2} \mathrm{~mL}, 0.14 \mathrm{mmol}\right)$. The reaction mixture was stirred for $10 \mathrm{~min}$, and then warmed to room temperature. After reprecipitation from $\mathrm{CH}_{2} \mathrm{Cl}_{2}(2 \mathrm{~mL}) / \mathrm{MeOH}(100 \mathrm{~mL})$, the formed polymer was dried under reduced pressure to give a diblock copolymer $\mathbf{C B}$ as white solid in $86 \%$ yield (64 mg). $M_{\mathrm{n}}=265,000 . M_{\mathrm{w}} / M_{\mathrm{n}}=1.15$. Anal. Calcd for $\left(\mathrm{C}_{7} \mathrm{H}_{10}\right)_{0.5}\left(\mathrm{C}_{13} \mathrm{H}_{17} \mathrm{NO}_{2}\right)_{0.5}: \mathrm{C}, 76.64 ; \mathrm{H}, 8.68 ; \mathrm{N}$, 4.47\%. Found: C, 75.17; H, 8.33; N, 4.82\%.

The ${ }^{1} H$ NMR Monitoring for Observation of Active Species during Diblock Copolymerization of Monomers $\boldsymbol{B C}$

To a $\mathrm{CD}_{2} \mathrm{Cl}_{2}(0.50 \mathrm{~mL})$ solution of initiator $\mathbf{3}(2.5 \times$ $10^{-2} \mathrm{M}$ solution in $\mathrm{CD}_{2} \mathrm{Cl}_{2}, 0.40 \mathrm{~mL}, 0.01 \mathrm{mmol}, 10$ mol \%) in an NMR tube was added monomer $\mathbf{B}$ $\left(0.1 \mathrm{~mL}, 0.1 \mathrm{mmol}, 1.0 \mathrm{M}\right.$ solution in $\left.\mathrm{CD}_{2} \mathrm{Cl}_{2}\right)$ at room temperature. The color of the reaction mixture was changed from green to brown immediately. The ${ }^{1} \mathrm{H}$ NMR spectra $(300 \mathrm{MHz})$ were recorded $3 \mathrm{~min}$ and $30 \mathrm{~min}$ later. Then, monomer $\mathbf{C}(0.1 \mathrm{~mL}, 0.1 \mathrm{mmol}$, $1.0 \mathrm{M}$ solution in $\mathrm{CD}_{2} \mathrm{Cl}_{2}$ ) was added to the resulting reaction mixture. The ${ }^{1} \mathrm{H}$ NMR spectra $(300 \mathrm{MHz})$ were again recorded $1 \mathrm{~min}$ and $3 \mathrm{~min}$ later. The ${ }^{1} \mathrm{H}$ NMR spectra $(300 \mathrm{MHz})$ were recorded $1 \mathrm{~min}$ after addition of ethyl vinyl ether $\left(20 \times 10^{-3} \mathrm{~mL}\right.$, $0.2 \mathrm{mmol})$.

\section{Synthesis of Random Copolymer $\boldsymbol{B}+\boldsymbol{C}$ at $-15^{\circ} \mathrm{C}$}

To a mixture of monomer $\mathbf{B}\left(4.9 \times 10^{-2} \mathrm{~mL}, 0.24\right.$ $\mathrm{mmol}$ ) and monomer $\mathbf{C}(23 \mathrm{mg}, 0.24 \mathrm{mmol})$ in dichloromethane $(1.5 \mathrm{~mL})$ was added initiator $\mathbf{3}(1.45 \times$ $10^{-3} \mathrm{M}$ stock solution in $\mathrm{CH}_{2} \mathrm{Cl}_{2}, 0.5 \mathrm{~mL}, 0.72 \times$ $10^{-3} \mathrm{mmol}, 0.3 \mathrm{~mol} \%$ ) at $-15^{\circ} \mathrm{C}$. The reaction mixture was stirred for $12 \mathrm{~h}$ at $-15^{\circ} \mathrm{C}$ and quenched with ethyl vinyl ether $\left(1.4 \times 10^{-2} \mathrm{~mL}, 0.14 \mathrm{mmol}\right)$. The reaction mixture was stirred for $10 \mathrm{~min}$, and then warmed to room temperature. Reprecipitation from $\mathrm{CH}_{2} \mathrm{Cl}_{2}(2 \mathrm{~mL}) / \mathrm{MeOH}(100 \mathrm{~mL})$ and drying under re- 
Table I. ROMP of polar norbornenes A, B, and parent $\mathbf{C}$ with initiator $\mathbf{3}$

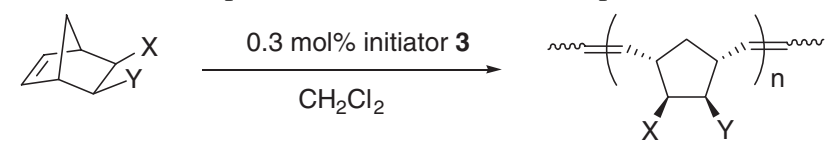

A: $X, Y=C N$, COOEt $\quad$ B: $X, Y=C N, C^{n} B u \quad$ C: $X, Y=H, H$

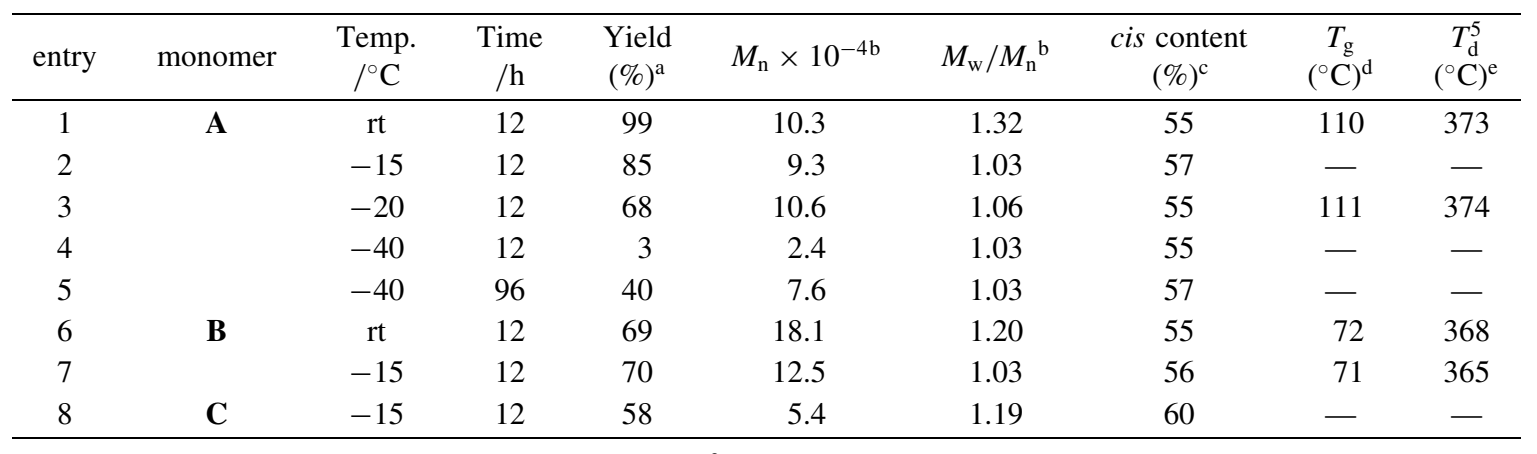

Conditions; $\mathrm{CH}_{2} \mathrm{Cl}_{2}(1 \mathrm{~mL})$, initiator $3\left(0.72 \times 10^{-3} \mathrm{mmol}, 0.3 \mathrm{~mol} \%\right)$, and monomer $(0.24 \mathrm{mmol}) .{ }^{a}$ Isolated yield after reprecipitation, ${ }^{\mathrm{b}}$ Determined by GPC with polystyrene standards, ${ }^{\mathrm{c}}$ Determined by ${ }^{1} \mathrm{H}$ NMR, ${ }^{\mathrm{d}}$ Measured in a nitrogen atmosphere with a heating rate of $10^{\circ} \mathrm{C} / \mathrm{min},{ }^{\mathrm{e}} \mathrm{Temperature}$ at $5 \%$ weight loss.

duced pressure afforded random copolymer BC in $74 \%$ yield $(55 \mathrm{mg})$ as white solid. $M_{\mathrm{n}}=194,000$. $M_{\mathrm{w}} / M_{\mathrm{n}}=1.04$. Anal. Calcd for $\left(\mathrm{C}_{13} \mathrm{H}_{17} \mathrm{NO}_{2}\right)_{0.5^{-}}$ $\left(\mathrm{C}_{7} \mathrm{H}_{10}\right)_{0.5}: \mathrm{C}, 76.64 ; \mathrm{H}, 8.68 ; \mathrm{N}, 4.47 \%$. Found: $\mathrm{C}$, 75.81; H, 8.47; N, 4.54\%.

\section{RESULTS AND DISCUSSION}

\section{Homopolymerization of Monomers $\boldsymbol{A}-\boldsymbol{C}$}

The yields, GPC, cis contents around the double bonds in the polymer backbone, the results of DSC, and TGA of obtained polymers derived from monomer $\mathbf{A}$ under the experimental protocol at different temperatures are summarized in Table I.

When a solution of $\mathbf{3}(0.3 \mathrm{~mol} \%)$ in $\mathrm{CH}_{2} \mathrm{Cl}_{2}$ was added to a solution of monomer $\mathbf{A}$ in $\mathrm{CH}_{2} \mathrm{Cl}_{2}$ at room temperature, a gradual change in the color from green to yellow was observed. After $12 \mathrm{~h}$, the added monomer A was completely consumed. The reaction mixture was quenched by adding ethyl vinyl ether, and the polymer formed was precipitated by pouring the reaction mixture into methanol with vigorous stirring. Homopolymer A was obtained in quantitative yield with a broad PDI (1.32) (entry 1$).{ }^{33}$ Since polydispersity is to some extent controlled by the relative rates of initiation $\left(k_{\mathrm{i}}\right)$ and propagation $\left(k_{\mathrm{p}}\right)$, narrow PDIs are obtained when the initiation rate is in the range of the propagation rate or faster. We believe that the relatively high PDI of the polymer obtained by the polymerization of monomer $\mathbf{A}$ with catalyst $\mathbf{3}$ at room temperature can be attributed to a smaller value of $k_{\mathrm{i}} / k_{\mathrm{p}} \cdot{ }^{2 \mathrm{~d}}$ Hence, to reduce the PDI of polymers down to less than 1.1, we conducted the polymerization at lower temperature. As hoped, the same homopolymer A with a narrower PDI (1.03) was obtained when the polymerization was conducted at $-15^{\circ} \mathrm{C}$ (entry 2). This demonstrates that $\mathbf{3}$ can initiate the polymerization rapidly even at $-15^{\circ} \mathrm{C}$ and that chain-transfer reactions during the polymerization are suppressed at low temperature. In spite of possible intramolecular or intermolecular coordination of a cyano group, the narrow PDI of the resulting polymer shows that the presence of a cyano group in the monomer $\mathbf{A}$ does not hamper the living polymerization. To the best of our knowledge, this is the first example that demonstrates the compatibility of a cyano group in the living ROMP using initiator 3. Rather lower temperature at $-20^{\circ} \mathrm{C}$ (entry 3 ) gave a similar result, whereas at $-40^{\circ} \mathrm{C}$ (entry 4) the polymerization is not efficient. Longer reaction time $(96 \mathrm{~h})$ at $-40^{\circ} \mathrm{C}$ improved the yield of homopolymer A to $40 \%$ (entry 5). In addition, the results of homopolymerizations of monomers $\mathbf{B}$ and $\mathbf{C}$ at room temperature or $-15^{\circ} \mathrm{C}$ are also summarized in Table I. Both the homopolymerization using the more sterically demanding monomer $\mathbf{B}$ and the less voluminous monomer $\mathbf{C}$ were shown to be living polymerizations with narrow PDI of 1.03 (entry $6 v s$ entry 7) at $-15^{\circ} \mathrm{C}$.

Homopolymers $\mathbf{A}$ and $\mathbf{B}$ under different reaction conditions displayed similar glass transition temperatures $\left(T_{\mathrm{g}} \mathrm{s}\right)$ and thermal stabilities (entries 1 vs 3 and entries $6 v s$ 7). The small differences observed may be a consequence of molecular weight and/or tacticity differences, but no crystalline melting point was detected. The glass transition temperatures $\left(T_{\mathrm{g}}\right)$ of the polymers obtained from ethyl monomer $\mathbf{A}$ are significantly higher $\left(110^{\circ} \mathrm{C}\right)$ than those observed for polymer derived from $n$-butyl monomer $\mathbf{B}\left(72^{\circ} \mathrm{C}\right)$ under the same reaction conditions. This is probably a consequence of softer side groups resulting from the flex- 

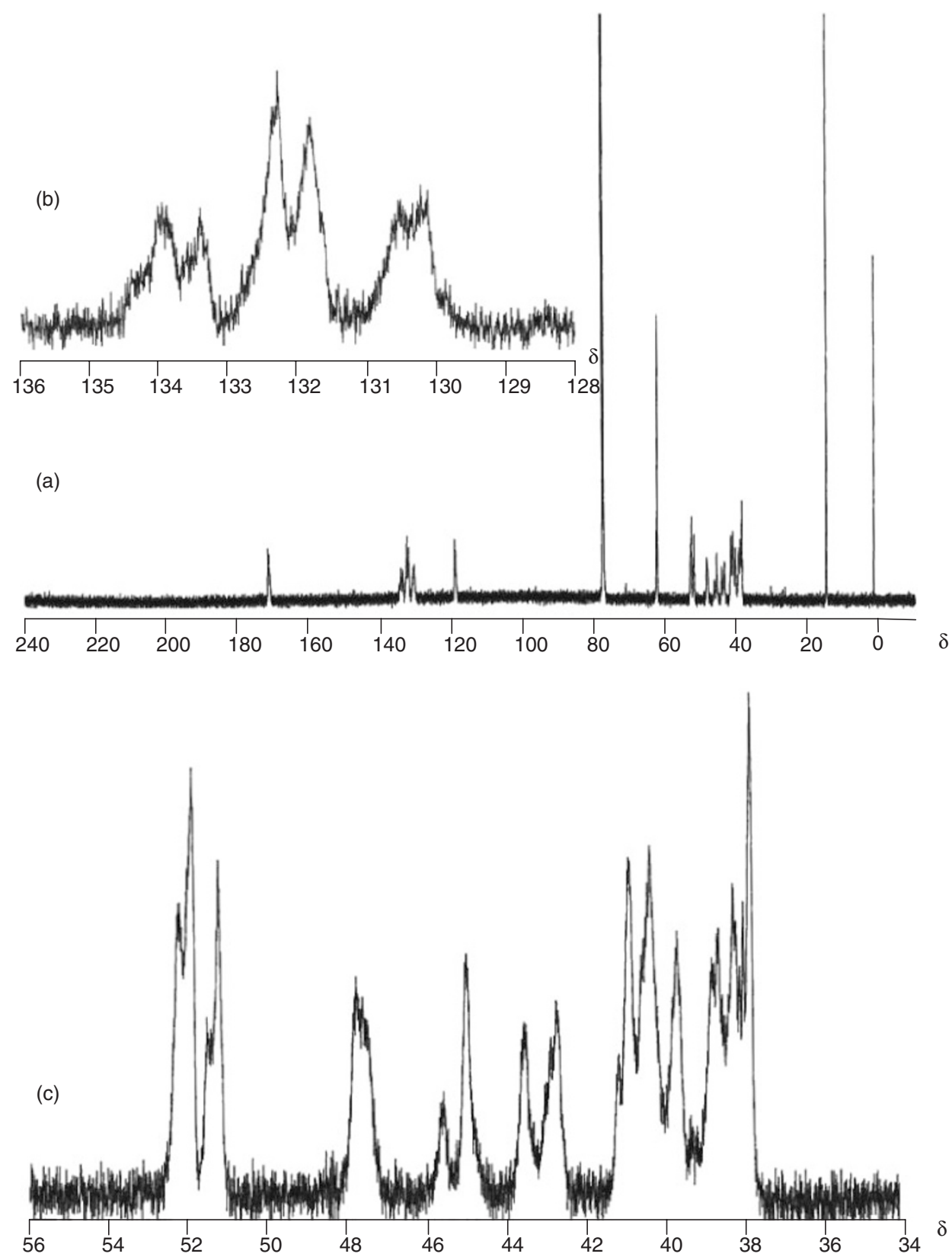

Figure 2. The ${ }^{13} \mathrm{C}\left\{{ }^{1} \mathrm{H}\right\}$ NMR spectra $\left(150 \mathrm{MHz}, \mathrm{CDCl}_{3}\right)$ of homopolymer $\mathbf{A}$. a) full scale, b) the olefinic region, and c) the methine carbon region.

ible $n$-butyl group. It is known that introduction of a cyano group into the polymer backbone can cause an upward shift of $T_{\mathrm{g}} .{ }^{34}$ Under the experimental protocol adopted, a 5\% weight loss was observed for polymers $\mathbf{A}$ and $\mathbf{B}$ at about $365-374{ }^{\circ} \mathrm{C}$.

The polymers obtained from $\mathbf{A}$ and $\mathbf{B}$ were soluble in chloroform, dichloromethane, tetrahydrofuran and insoluble in methanol. Infrared spectral signals characteristic of the cyano group and ester carbonyl group were observed at 2243 and $1734 \mathrm{~cm}^{-1}$, respectively. The ${ }^{1} \mathrm{H}$ and ${ }^{13} \mathrm{C}\left\{{ }^{1} \mathrm{H}\right\}$ NMR spectra of the polymers obtained were in agreement with the structures proposed and showed similar patterns of chemical shifts. The monomers $\mathbf{A}$ and $\mathbf{B}$ employed are isomerically pure but a mixture of enantiomers ( $\mathrm{R}$ and $\mathrm{S}$ ). Accordingly, addition to the configuration around the double bond (cis or trans), the polynorbornene main chain consists of eight different diads based on head-tail isomerism and tacticity (syndiotactic (r) or isotactic (m)). As shown by the ${ }^{13} \mathrm{C}\left\{{ }^{1} \mathrm{H}\right\}$ NMR spectra of homopolymer A illustrated in Figure 2, the resonances in the olefinic and methine carbon regions were quite broad and complicated, which indicates a lack of stereoregularity of the main chain. An analysis revealed that the double bonds formed between the rings are 56\% cis configuration in these catalyst systems. ${ }^{35} \mathrm{Cis}$ contents for homopolymers B (55\%) and C (60\%) were determined similarly. 
Table II. Summary of yields and GPC data with various $[\mathrm{M}] /[\mathrm{I}]$ ratios for homopolymer $\mathbf{A}$ using initiator 3 at $-15^{\circ} \mathrm{C}$

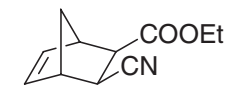

A

\begin{tabular}{cccccc}
\hline $\begin{array}{c}{[\mathrm{M}] /[\mathrm{I}]} \\
\text { (mol ratio) }\end{array}$ & $\begin{array}{c}\mathrm{X} \\
\mathrm{mol} \%\end{array}$ & $\begin{array}{c}\text { Yield } \\
(\%)^{\mathrm{a}}\end{array}$ & $\begin{array}{c}\text { Calculated } \\
M_{\mathrm{n}} \times 10^{-4}\end{array}$ & $\begin{array}{c}\text { Observed } \\
M_{\mathrm{n}} \times 10^{-4 \mathrm{~b}}\end{array}$ & $M_{\mathrm{w}} / M_{\mathrm{n}}{ }^{\mathrm{b}}$ \\
\hline 143 & 0.70 & 75 & 2.7 & 4.4 & 1.03 \\
200 & 0.50 & 71 & 3.8 & 5.5 & 1.02 \\
333 & 0.30 & 85 & 6.3 & 9.3 & 1.03 \\
500 & 0.20 & 91 & 9.6 & 13.9 & 1.03 \\
714 & 0.14 & 88 & 13.6 & 18.0 & 1.04 \\
1000 & 0.10 & 80 & 19.1 & 29.6 & 1.06 \\
\hline
\end{tabular}

Conditions; $\mathrm{CH}_{2} \mathrm{Cl}_{2}(1 \mathrm{~mL})$ and monomer $\mathbf{A}(0.24 \mathrm{mmol})$ at $-15^{\circ} \mathrm{C}$ for $12 \mathrm{~h}$. ${ }^{\mathrm{a}}$ Isolated yield after reprecipitation, ${ }^{\mathrm{b}}$ Determined by GPC with polystyrene standards.

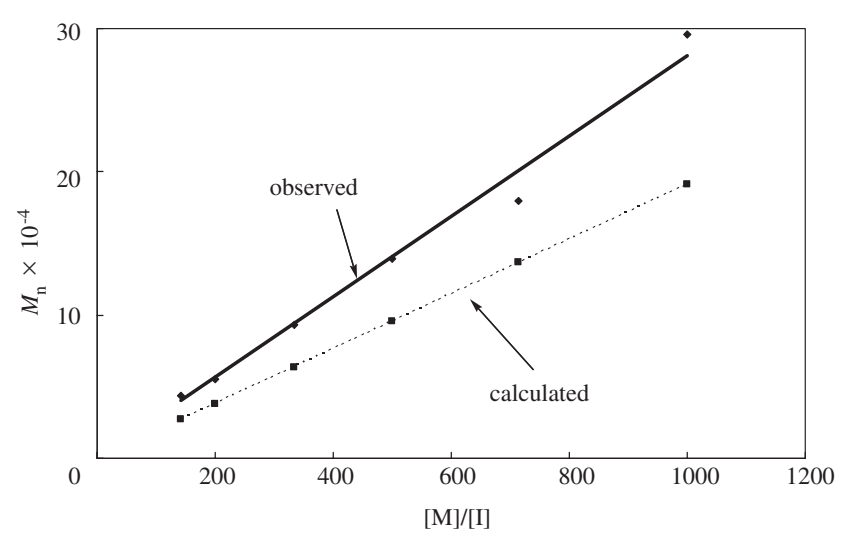

Figure 3. Plot of $[\mathrm{M}] /[\mathrm{I}] \quad v s M_{\mathrm{n}}$ for homopolymer $\mathbf{A}$ at $-15^{\circ} \mathrm{C}$.

The molecular weights of the homopolymer $\mathbf{A}$ were varied by controlling the molar ratio of monomer to initiator ([M]/[I]). A series of homopolymers A were synthesized in order to demonstrate that the polymerization occurs in a living manner. The results are summarized in Table II. In all cases the added monomer $\mathbf{A}$ was completely consumed after $12 \mathrm{~h}$. As shown in Figure 3, a linear relationship is obtained by plotting the number-average molecular weight values ( $M_{\mathrm{n}} v s$ polystyrene) of homopolymer $\mathbf{A}$ as a function of $[\mathrm{M}] /[\mathrm{I}]$. The occurrence of living polymerization is supported by the good correlation between the theoretical $M_{\mathrm{n}}$ values and those observed for obtained polymers. Noteworthy is that a linear relationship between $M_{\mathrm{n}}$ and $[\mathrm{M}] /[\mathrm{I}]$ maintains narrow PDIs $(<1.06)$. The control of the molecular weight is attributed to the fact that for $\mathbf{3}, k_{\mathrm{i}} / k_{\mathrm{p}}$ is high enough that all the chains initiate and grow at a similar rate (vide infra). ${ }^{2 \mathrm{e}, 24 \mathrm{a}, 30 \mathrm{a}}$ For this reason, catalyst $\mathbf{3}$ promotes living ROMP for a novel polar norbornene $\mathbf{A}$ bearing
Table III. Effect of reaction time on $M_{\mathrm{n}}$ of the homopolymer $\mathbf{A}$ at $-15^{\circ} \mathrm{C}$

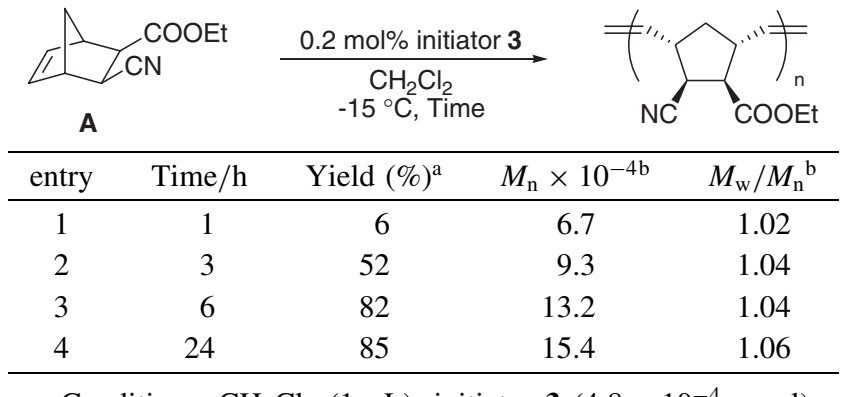

Conditions; $\mathrm{CH}_{2} \mathrm{Cl}_{2}(1 \mathrm{~mL})$, initiator $3\left(4.8 \times 10^{-4} \mathrm{mmol}\right)$, and monomer $\mathbf{A}(0.24 \mathrm{mmol})$ at $-15{ }^{\circ} \mathrm{C}$. a Isolated yield after reprecipitation, ${ }^{\mathrm{b}}$ Determined by GPC with polystyrene standards.

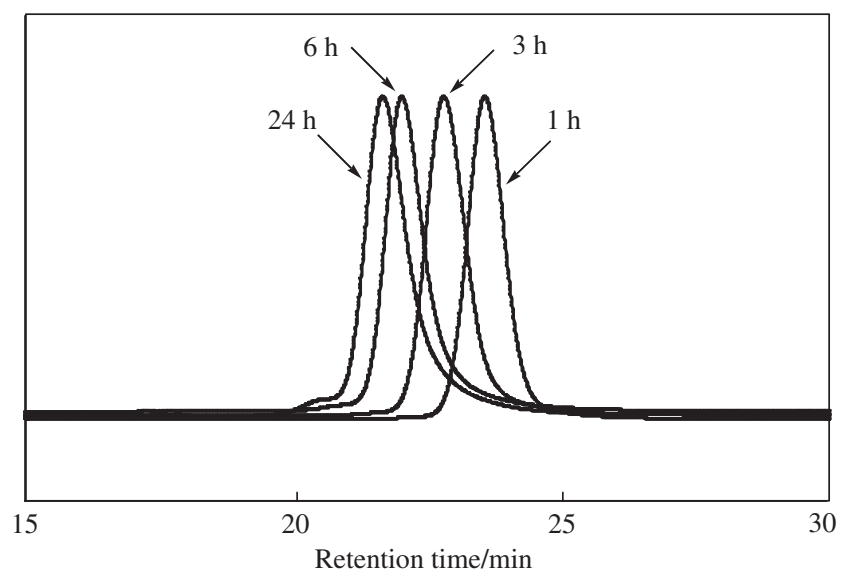

Figure 4. Gel permeation chromatograms of homopolymer A at $-15^{\circ} \mathrm{C}$.

both cyano and ester groups with both higher activity and better molecular weight control. The experimental $M_{\mathrm{n}}$ values cannot be directly compared to the expected $M_{\mathrm{n}}$ values because the GPC system used was calibrated using polystyrene standards.

We next investigated the living nature of homopolymerization of monomer $\mathbf{A}$ by changing the polymerization time. Table III shows the results of yields and GPC data as functions of the reaction time. Figure 4 shows the GPC traces of the homopolymers obtained. These shift to higher molecular weight according to polymerization time. The molecular weight increased dramatically for the homopolymer $\mathbf{A}$ after $24 \mathrm{~h}$ vs $1 \mathrm{~h}$ and no residual base polymer was observed. Although the PDI increased slightly from 1.02 to 1.06 , this observation demonstrates the absence of chain transfer and chain termination consistent with homopolymerization of monomer $\mathbf{A}$ proceeding at $-15^{\circ} \mathrm{C}$ in a living manner.

\section{Mechanistic and Kinetic Studies on Homopolymeriza- tion of Monomer A}

The living homopolymerization reactions of mono- 
mer $\mathbf{A}$ initiated with $\mathbf{3}$ were monitored by ${ }^{1} \mathrm{H}$ NMR in $\mathrm{CD}_{2} \mathrm{Cl}_{2}$ at room temperature until the monomer was consumed completely. The ${ }^{1} \mathrm{H}$ NMR spectrum measured 1 min after the addition of $\mathbf{A}$ to a $\mathrm{CD}_{2} \mathrm{Cl}_{2}$ solution of initiator $\mathbf{3}$ showed a sharp singlet due to the initiator alkylidene hydrogen at $\delta 19.1$. This was replaced by a broad downfield signal assigned to alkylidene hydrogens at $\delta 18.6$ probably attached to esterand/or cyano-stabilized carbene species. ${ }^{13 \mathrm{~b}}$ The continuous observation during polymerization of a broad resonance at $\delta 18.6$ associated with an active species derived from initiator 3 is a general feature of all polymerizations conducted even though monomer $\mathbf{A}$ was present in a large excess. After addition of ethyl vinyl ether, the alkylidene hydrogens signal shifted to $\delta$ 13.6. Using initiator $\mathbf{3}$, it appears that the initiation rate constant $k_{\mathrm{i}}$ for the living polymerization of polar norbornenes is considerably greater than the propagation rate constant $k_{\mathrm{p}}$ as reported previously. ${ }^{30 \mathrm{a}}$

Because the reaction rate is possibly dependent on the steric bulk of the ester moieties of norbornenes, we next investigated comparative reactivity for living ring-opening metathesis polymerizations of monomers $\mathbf{A}$ and $\mathbf{B}$ initiated by $\mathbf{3}$. The in situ monitoring of the individual homopolymerizations of monomers $\mathbf{A}$ and $\mathbf{B}$ were performed in a series of the ${ }^{1} \mathrm{H}$ NMR tube experiments. In $\mathrm{CD}_{2} \mathrm{Cl}_{2}$, with $[\mathrm{I}]=6.3 \times 10^{-4}$ $\mathrm{M},[\mathrm{M}]=0.208 \mathrm{M},[\mathrm{M}] /[\mathrm{I}]=333$, the rate of disappearance of each monomer was observed. When $\left(\ln [\right.$ monomer $\left.]-\ln [\text { monomer }]_{0}\right)$ was plotted $v s$ time first-order linear plots were obtained for either of the homopolymerizations (Figure 5). From these plots the rate constants were found to be $9.47 \times 10^{-4} \mathrm{~s}^{-1}$ $\left(\mathrm{t}_{1 / 2}=11.9 \mathrm{~min}\right)$ for monomer $\mathbf{A}$ and $7.87 \times 10^{-4}$ $\mathrm{s}^{-1}\left(\mathrm{t}_{1 / 2}=13.5 \mathrm{~min}\right)$ for monomer B. However, repeated experiments did not allow the determination of the ratio of rate constants for propagation to initiation, $k_{\mathrm{p}} / k_{\mathrm{i}}$, due to the rapid initiation of catalyst $3 .{ }^{1}$

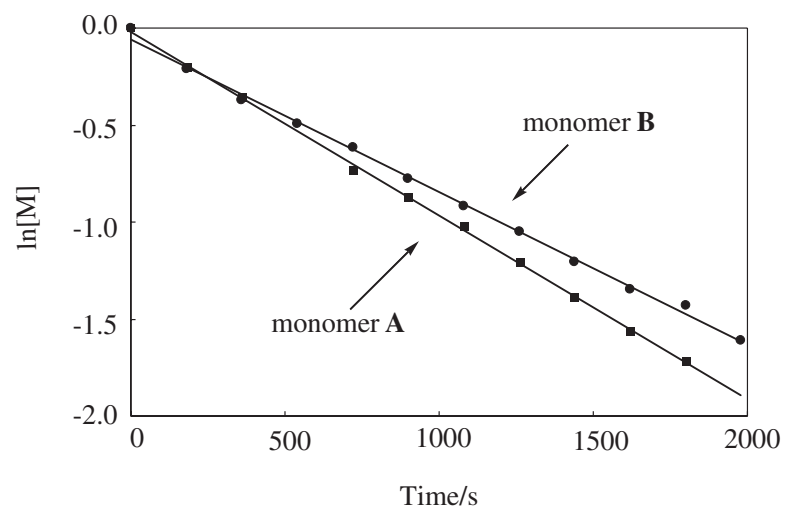

Figure 5. First-order plots $([\mathrm{M}]=0.208 \mathrm{M})$ in homopolymerization of monomers $\mathbf{A}$ or $\mathbf{B}$ in $\mathrm{CD}_{2} \mathrm{Cl}_{2}$ under $\mathrm{Ar}$ at room temperature initiated by $\mathbf{3}\left([\mathrm{I}]=6.3 \times 10^{-4} \mathrm{M}\right)$.

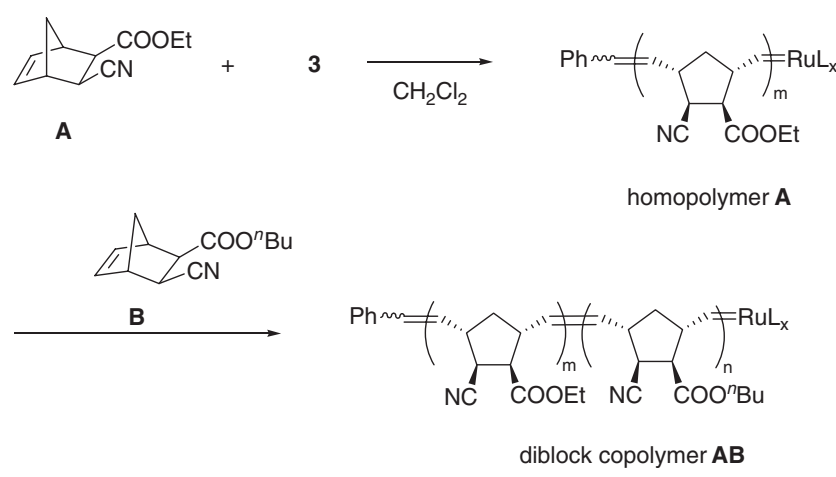

Scheme 1.

\section{Synthesis of Diblock Copolymers $\boldsymbol{A B}$ and $\boldsymbol{B} \boldsymbol{A}$}

Because the study of copolymerization by ringopening metathesis polymerization may provide a new route to tune material properties through combinations of various monomers, the living nature of the present ROMP was confirmed by preparing $\mathbf{A B}$ diblock copolymers by sequential addition of doubly functionalized polar norbornene derivatives $\mathbf{A}$ then B (Scheme 1). The first monomer A ([M]/[I] = 100) is added to a solution of catalyst 3 in $\mathrm{CH}_{2} \mathrm{Cl}_{2}$ at $-15^{\circ} \mathrm{C}$. This is followed by the addition of monomer B $([\mathrm{M}] /[\mathrm{I}]=100)$ after $6 \mathrm{~h}$. The resulting diblock copolymer AB had a $M_{\mathrm{n}}$ of 75,000. Moreover, the low PDIs (1.03) determined by GPC indicated well behaved growth of the second monomer $\mathbf{B}$.

Accordingly, we polymerized monomer B ([M]/ $[\mathrm{I}]=100)$ and, subsequently, monomer $\mathbf{A}([\mathrm{M}] /[\mathrm{I}]=$ 100) following the same protocol as for copolymer AB. The same procedure was applied to the GPC analysis, where a monomodal chromatogram had been obtained. For diblock copolymer BA the apparent $M_{\mathrm{n}}$ was 71,000 with an apparent polydispersity index of 1.03 .

A DSC thermogram of the synthesized diblock copolymers AB (Figure 6a) and BA (Figure 6b) shows the same features having two glass transition temperatures characteristic of poly(block $\mathbf{A}$ ), about $111^{\circ} \mathrm{C}$, and poly(block B), about $73^{\circ} \mathrm{C}$. This indicates the incompatibility of the segments $\mathbf{A}$ and $\mathbf{B}$ in the diblock copolymer systems. The results of elemental analyses also supported the presence of both monomers in a 1:1 ratio, although incomplete combustion of the polymers led to slight deviations from the calculated value, especially for carbon.

In order to compare with block copolymers having separate blocks of monomer $\mathbf{A}$ and $\mathbf{B}$, the corresponding random copolymer $\mathbf{A}+\mathbf{B}$ was synthesized by subjecting a 1:1 mixture of monomer $\mathbf{A}$ and $\mathbf{B}$ to identical living ROMP conditions using $\mathbf{3}$ as a catalyst at $-15^{\circ} \mathrm{C}$. For the random copolymer $\mathbf{A}+\mathbf{B}, M_{\mathrm{n}}$ was 190,000 and PDI of 1.09 at $[\mathrm{M}] /[\mathrm{I}]=667$. The $T_{\mathrm{g}}$ 

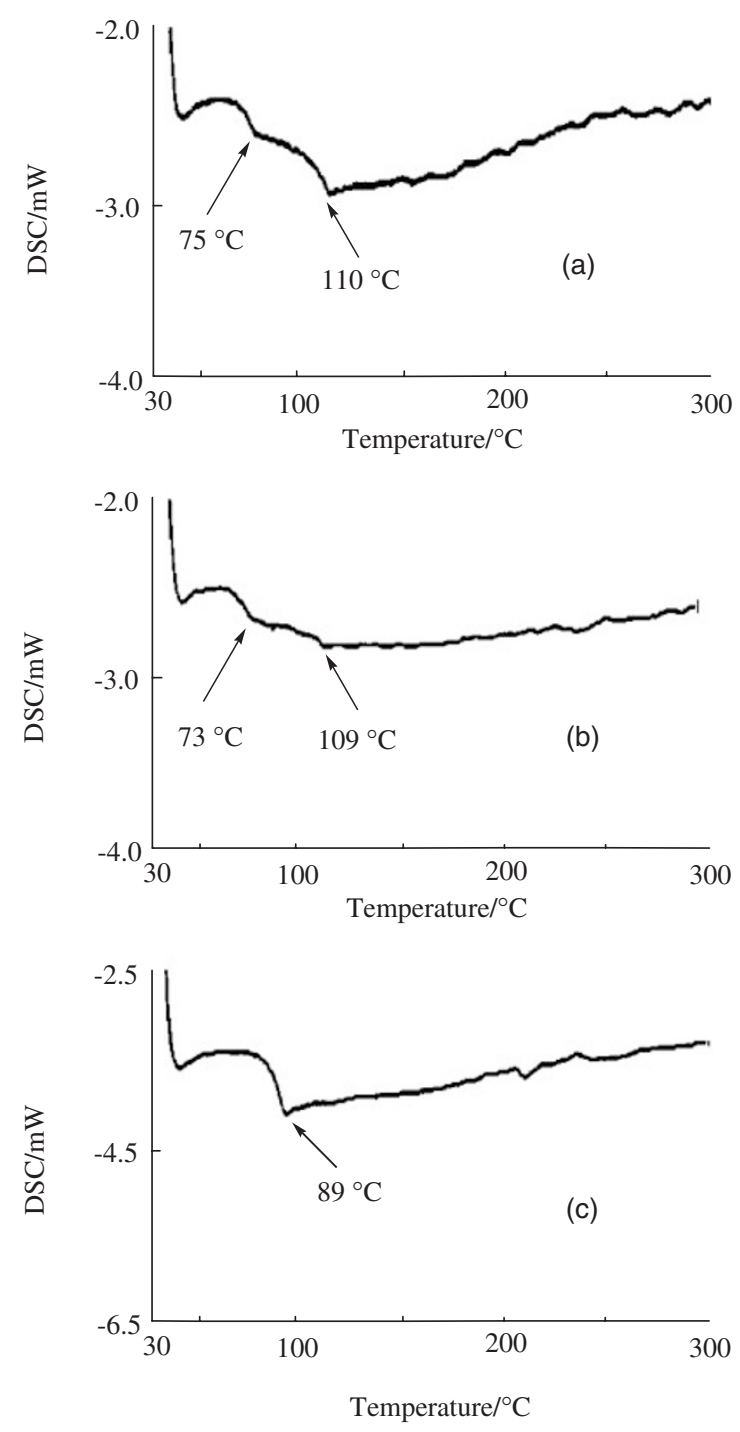

Figure 6. DSC thermograms (2nd heating) of (a) diblock copolymer AB. (b) diblock copolymer BA. (c) random copolymer A+B. All copolymerizations were initiated by 3 at $-15^{\circ} \mathrm{C}$.

value of random copolymer $\mathbf{A}+\mathbf{B}$ was found to be $89^{\circ} \mathrm{C}$ (Figure 6c). This indicates a random distribution of each monomer in the random copolymer because of the drastic change in $T_{\mathrm{g}}$ for random copolymer $\mathbf{A}+\mathbf{B}$ to the value in the range of $T_{\mathrm{g}}$ of $73^{\circ} \mathrm{C}$ and $111^{\circ} \mathrm{C}$ observed in the diblock copolymers $\mathbf{A B}$ and $\mathbf{B A}$.

The ${ }^{1} \mathrm{H}$ NMR spectra of the diblock copolymers $\mathbf{A B}$ and $\mathbf{B A}$, and random copolymer $\mathbf{A}+\mathbf{B}$ were virtual superpositions of those of the two homopolymers $\mathbf{A}$ and $\mathbf{B}$ (Figure 7). Although the ratio of $\mathrm{m}$ (average number of repeating units for monomer $\mathbf{A}$ ) to $\mathrm{n}$ (average number of repeating units for monomer $\mathbf{B}$ ) could not be determined from the integration of the ${ }^{1} \mathrm{H}$ NMR spectrum due to overlapping signals, the results of elemental analyses indicate that the obtained copolymers consist of both monomers $\mathbf{A}$ and $\mathbf{B}$ in a $1: 1$ ratio.

\section{Copolymerization Involving $\boldsymbol{C}$ as a Comonomer}

Norbornene $(\mathbf{C})$ was reported to undergo controlled living polymerization by catalyst $\mathbf{3}$ with narrow PDIs. ${ }^{30 \mathrm{~b}}$ Thus, we elucidated the synthesis of diblock copolymers involving $\mathbf{C}$ such as $\mathbf{B C}$ and $\mathbf{C B}$, monitoring the ${ }^{1} \mathrm{H}$ NMR spectra during copolymerization. In a typical example, initiator $3(10 \mathrm{~mol} \%)$ in $\mathrm{CD}_{2} \mathrm{Cl}_{2}$ was added to a solution of monomer $\mathbf{B}$ and the ${ }^{1} \mathrm{H}$ NMR spectrum was recorded after $3 \mathrm{~min}$. As observed in homopolymerization of monomer $\mathbf{A}$, the ${ }^{1} \mathrm{H}$ NMR spectrum showed broad multiplets at $\delta$ 18.6 in place of the initial alkylidene hydrogen at $\delta$ 19.1 and also shows signals assigned to the growing homopolymer B. Meanwhile, no signals due to the initiator $\mathbf{3}$ or monomer $\mathbf{B}$ were detected, implying that both are completely consumed at this stage. A solution of $\mathbf{C}$ as a comonomer was added to the living polymerization mixture and the ${ }^{1} \mathrm{H}$ NMR spectrum was measured after $1 \mathrm{~min}$. Instantly, the ${ }^{1} \mathrm{H}$ NMR signals for the polymer $\mathbf{C}$ appeared and a corresponding decrease in the relative intensity of the signals associated with monomer $\mathbf{C}$ was observed. Although the new monomer $\mathbf{C}$ was added, a same propagating alkylidene signal at $\delta 18.6$ was observed, indicating the same active species for both monomers $\mathbf{B}$ and $\mathbf{C}$. The reaction was monitored until monomer $\mathbf{C}$ was completely consumed. The isolated diblock copolymer BC exhibited a single mode molecular weight distribution of $1.03\left(M_{\mathrm{n}}=247,000\right)$. In a sharp contrast, however, diblock copolymer CB prepared from the opposite order of monomer addition, i.e., showed a broadening of the molecular weight distribution of $1.15\left(M_{\mathrm{n}}=265,000\right)$, which implied that the illbehaved initiation of the polymer $\mathbf{C}$ could presumably be attributed to the rapid propagation. With initiator $\mathbf{3}$, in fact, homopolymerization of polar functionalized monomers $\mathbf{A}$ and $\mathbf{B}$ were distinctly slower than that of the parent norbornene $(\mathbf{C})$, based on half-lives determined by arrayed NMR spectroscopy for all monomers at room temperature: for $\mathbf{A} 11.9 \mathrm{~min}$, for $\mathbf{B}$ $13.5 \mathrm{~min}$, but, $\mathbf{C}<1 \mathrm{~min}$.

\section{CONCLUSIONS}

We have demonstrated that catalyst $\mathbf{3}$ bearing an $\mathrm{N}$-heterocyclic carbene and 3-bromopyridine ligands accomplishes living homopolymerization and block and random copolymerization for the parent norbornene $(\mathbf{C})$ and derivatives containing cyano and ester functionalities ( $\mathbf{A}$ and $\mathbf{B}$ ). The polymers have narrow polydispersity indices (PDI $=1.02-1.15)$ at $-15^{\circ} \mathrm{C}$. Because complete initiation and an outstanding tolerance of functional groups are provided, our results pave the way for the rational preparation of well-defined homopolymers and copolymers of both cyano 


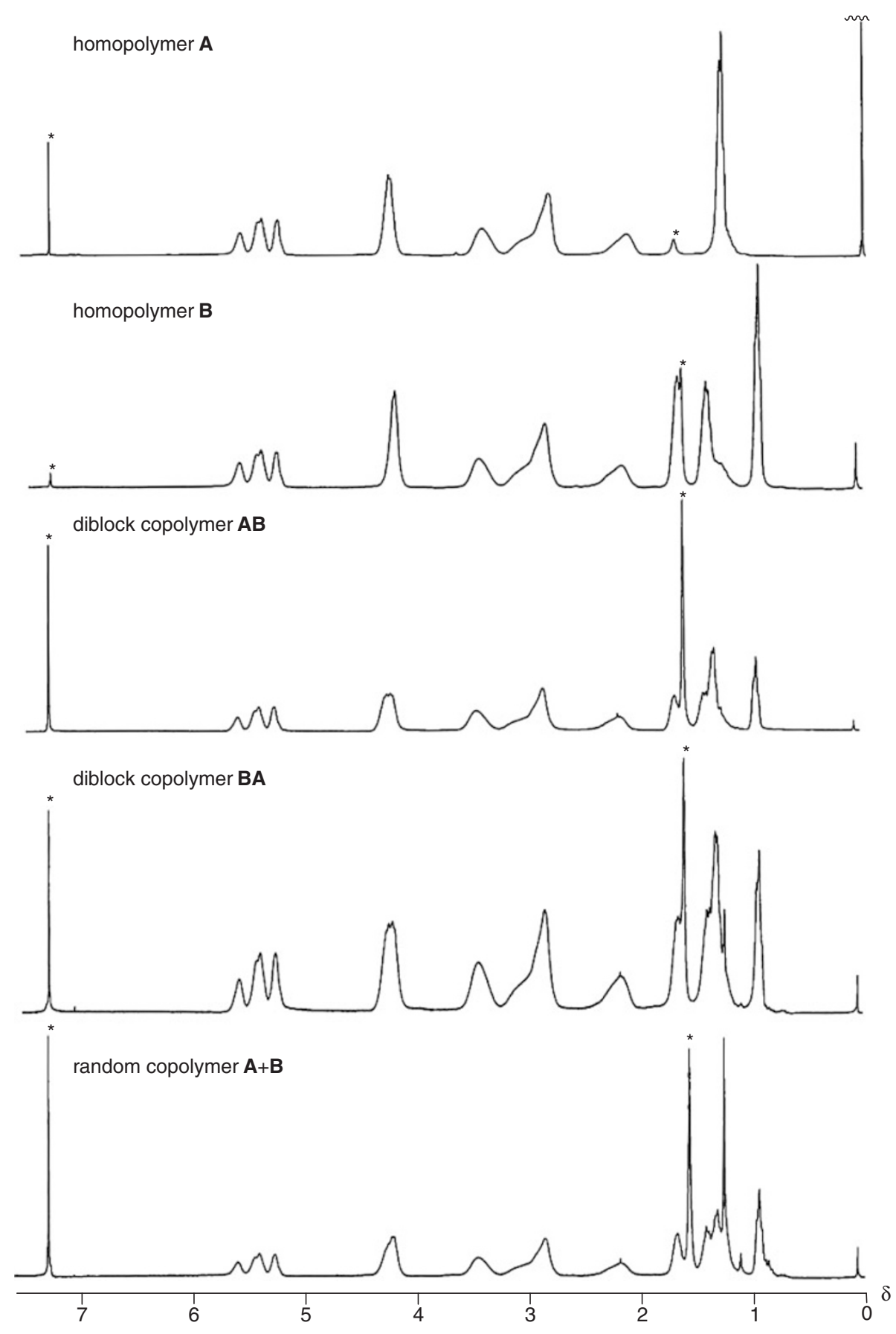

Figure 7. The ${ }^{1} \mathrm{H}$ NMR spectra $\left(300 \mathrm{MHz}, \mathrm{CDCl}_{3}\right)$ of homopolymers $\mathbf{A}$ and $\mathbf{B}$, diblock copolymers $\mathbf{A B}$ and $\mathbf{B A}$, and random copolymer $\mathbf{A}+\mathbf{B}$. The signal with an asterisk is due to the solvent and the contaminated water.

and ester functionalized monomers using ruthenium initiators. Thermal analysis also shows that there is a trend to lower $T_{\mathrm{g}}$ with increasing length of pendant alkyl group of the ester moiety. The propagating species from the first monomer was found to be stable over the course of the polymerization and the second addition of the other monomer resulted in the continuation of the polymerization to afford diblock copolymers.

In addition to synthesis of the present cycloolefin polymers, we are pursuing a simple, general method to hydrogenate these polymers toward the novel optoelectronic materials and will report them in future publications.

Acknowledgment. The authors gratefully thank Prof. Hiroshi Nakazawa and Dr. Masumi Itazaki at Osaka City University for measurements of elemental analyses. The present work was financially supported by Industrial Technology Research Grant Program in 2007 from New Energy and Industrial Technology Development Organization (NEDO) of Japan. 


\section{REFERENCES}

1. K. J. Ivin and I. C. Mol, "Olefin Metathesis and Metathesis Polymerization,” Academic Press, San Diego, CA, 1997.

2. a) B. M. Novak, W. Risse, and R. H. Grubbs, Adv. Polym. Sci., 102, 47 (1992).

b) P. Schwab, R. H. Grubbs, and J. W. Ziller, J. Am. Chem. Soc., 118, 100 (1996).

c) R. H. Grubbs and E. Khosravi, Mater. Sci. Technol., 20, 65 (1999).

d) C. W. Bielawski and R. H. Grubbs, Angew. Chem., Int. Ed., 39, 2903 (2000).

e) M. S. Sanford, J. A. Love, and R. H. Grubbs, J. Am. Chem. Soc., 123, 6543 (2001).

f) T. M. Trnka and R. H. Grubbs, Acc. Chem. Res., 34, 18 (2001).

3. a) R. R. Schrock, Tetrahedron, 55, 8141 (1999).

b) M. R. Buchmeiser, Chem. Rev., 100, 1565 (2000).

c) A. Fürstner, Angew. Chem., Int. Ed., 39, 3012 (2000).

4. a) H. R. Allcock, W. R. Laredo, C. R. de Denus, and J. P. Taylor, Macromolecules, 32, 7719 (1999).

b) H. R. Allcock, C. R. de Denus, R. Prange, and W. R. Laredo, Macromolecules, 34, 2757 (2001).

5. a) V. Héroguez, E. Amédro, D. Grande, M. Fontanille, and Y. Gnanou, Macromolecules, 33, 7241 (2000).

b) U. Frenzel and O. Nuyken, J. Polym. Sci., Part A: Polym. Chem., 40, 2895 (2002).

c) V. Lapinte, P. de Fremont, V. Montembault, and L. Fontaine, Macromol. Chem. Phys., 205, 1238 (2004).

6. S. Riegler, C. Slugovc, G. Trimmel, and F. Stelzer, Macromol. Symp., 217, 231 (2004).

7. R. H. Grubbs and E. Khosravi, 'ROMP and related processes,' in "Synthesis of Polymers-A Volume of Materials Science and Technology," A.-D. Schluter Ed., WileyVCH, 1998, Chap. 3, p. 65.

8. a) S. T. Nguyen, L. K. Johnson, R. H. Grubbs, and J. W. Ziller, J. Am. Chem. Soc., 114, 3974 (1992).

b) S. T. Nguyen, R. H. Grubbs, and J. W. Ziller, J. Am. Chem. Soc., 115, 9858 (1993).

c) P. Schwab, M. B. France, J. W. Ziller, and R. H. Grubbs, Angew. Chem., Int. Ed., 34, 2039 (1995).

d) S. Kanaoka and R. H. Grubbs, Macromolecules, 28, 4707 (1995).

e) M. Weck, P. Schwab, and R. H. Grubbs, Macromolecules, 29, 1789 (1996).

9. a) V. C. Gibson, E. L. Marshall, M. North, D. A. Robson, and P. J. Williams, J. Chem. Soc., Chem. Commun., 1095 (1997).

b) S. C. G. Biagini, M. P. Coles, V. C. Gibson, M. R. Giles, E. L. Marshall, and M. North, J. Chem. Soc., Chem. Commun., 1097 (1997).

c) R. G. Davies, V. C. Gibson, M. North, and D. A. Robson, Polymer, 40, 5239 (1999).

10. For a review: A. Fürstner, in "Topics in Organometallic Chemistry: Alkene Metathesis in Organic Synthesis," A. Fürstner, Ed., Springer, Berlin, 1998, Vol. 1, p 37.

11. a) D. M. Lynn, S. Kanaoka, and R. H. Grubbs, J. Am. Chem. Soc., 118, 784 (1996). b) J. Louie, C. W. Bielawski, and R. H. Grubbs, J. Am. Chem. Soc., 123, 11312 (2001).

12. W. A. Herrmann, Angew. Chem., Int. Ed., 41, 1290 (2002).

13. a) C. Slugovc, S. Demel, and F. Stelzer, Chem. Commun., 2572 (2002).

b) S. Demel, W. Schoefberger, C. Slugovc, and F. Stelzer, J. Mol. Catal. A: Chem., 200, 11 (2003).

14. For a review: A. Fürstner, in "Topics in Organometallic Chemistry: Alkene Metathesis in Organic Synthesis," A. Fürstner, Ed., Springer, Berlin, 1998, Vol. 1, p 37.

15. R. H. Grubbs, "Handbook of Metathesis," Wiley-VCH, Weinheim, Germany, 2003, Vols. 2 and 3.

16. A. Fürstner, Angew. Chem., Int. Ed., 39, 3012 (2000).

17. C. Slugovc, S. Demel, S. Riegler, J. Hobisch, and F. Stelzer, J. Mol. Catal. A: Chem., 213, 107 (2004).

18. There are some reports using $\left(\mathrm{PCy}_{3}\right)_{2}(\mathrm{Cl})_{2} \mathrm{Ru}=\mathrm{CHPh}$ in the polymerization of nitrile and amine containing monomers; see,

a) D.-J. Liaw and C.-H. Tsai, Polymer, 41, 2773 (2000).

b) D.-J. Liaw and P.-L. Wu, J. Mol. Catal. A: Chem., 160, 35 (2000).

19. a) R. G. Davies, V. C. Gibson, M. B. Hursthouse, M. E. Light, E. L. Marshall, M. North, D. A. Robson, I. Thompson, A. J. P. White, D. J. Williams, and P. J. Williams, J. Chem. Soc., Perkin Trans., 1, 3365 (2001).

b) C. Bolm, C. Tanyeli, A. Grenz, and C. L. Dinter, $A d v$. Synth. Catal., 344, 649 (2002).

c) M. Kimura, H. Ueki, K. Ohta, K. Hanabusa, H. Shirai, and N. Kobayashi, Langmuir, 18, 7683 (2002).

d) J. M. Pollino, L. P. Stubbs, and M. Weck, Macromolecules, 36, 2230 (2003).

e) S. Demel, S. Riegler, K. Wewerka, W. Schoefberger, C. Slugovc, and F. Stelzer, Inorg. Chim. Acta, 345, 363 (2003).

20. M. Scholl, S. Ding, C. W. Lee, and R. H. Grubbs, Org. Lett., 1, 953 (1999).

21. a) T. Weskamp, W. C. Schattenmann, M. Spiegler, and W. A. Herrman, Angew. Chem., Int. Ed., 37, 2490 (1998).

b) T. Weskamp, F. J. Kohl, W. Hieringer, D. Gleich, and W. A. Herrman, Angew. Chem., Int. Ed., 38, 2416 (1999). c) J. Huang, E. D. Stevnes, S. P. Nolan, and J. L. Petersen, J. Am. Chem. Soc., 121, 2674 (1999).

22. a) T. Ueshima and S. Kobayashi, Jpn. Plast., 24, 11 (1974). b) W. J. Feast and B. Wilson, Polymer, 20, 1182 (1979).

c) W. J. Feast and B. Wilson, J. Mol. Catal., 8, 277 (1980). d) C. Edwige, A. Lattes, J. P. Laval, R. Mutin, J. M. Basset, and R. Nouguier, J. Mol. Catal., 8, 297 (1980).

e) J. Otton, Y. Colleuille, and J. Varagnat, J. Mol. Catal., 8, 313 (1980).

f) K. J. Ivin, J. J. Rooney, L. Bencze, J. G. Hamilton, L. M. Lam, G. Lapienis, B. S. R. Reddy, and H. H. Thoi, Pure Appl. Chem., 54, 447 (1982).

23. a) E. Årstad, A. G. M. Barrett, B. T. Hopkins, and J. Köbberling, Org. Lett., 4, 1975 (2002).

b) H. S. Bazzi and H. F. Sleiman, Macromolecules, 35, 9617 (2002)

c) A. Meyers and M. Weck, Macromolecules, 36, 1766 (2003).

24. M. S. Sanford, M. Ulman, and R. H. Grubbs, J. Am. Chem. Soc., 123, 749 (2001). 
25. a) C. W. Bielawski, D. Benitez, T. Morita, and R. H. Grubbs, Macromolecules, 34, 8610 (2001).

b) O. A. Scherman, H. M. Kim, and R. H. Grubbs, Macromolecules, 35, 5366 (2002).

26. a) Y. Yoshida, K. Goto, and Z. Komiya, J. Appl. Polym. Sci., 66, 367 (1997).

b) Y. Yoshida, M. Yoshinari, A. Iio, and Z. Komiya, Polym. J., 30, 819 (1998).

c) T. Otsuki, K. Goto, and Z. Komiya, J. Polym. Sci., Part A: Polym. Chem., 38, 4661 (2000).

27. a) S. Hayano, H. Kurakata, Y. Tsunogae, Y. Nakayama, Y. Sato, and H. Yasuda, Macromolecules, 36, 7422 (2003).

b) S. Hayano, H. Kurakata, D. Uchida, M. Sakamoto, N. Kishi, H. Matsumoto, Y. Tsunogae, and I. Igarashi, Chem. Lett., 32, 670 (2003).

c) S. Hayano and Y. Tsunogae, Chem. Lett., 34, 1520 (2005).

d) S. Hayano and Y. Tsunogae, Macromolecules, 39, 30 (2006).

e) S. Hayano, Y. Takeyama, Y. Tsunogae, and I. Igarashi, Macromolecules, 39, 4663 (2006).

28. a) Y. Nishihara, Y. Inoue, M. Itazaki, and K. Takagi, Org. Lett., 7, 2639 (2005). b) Y. Nishihara, Y. Inoue, S. Izawa, M. Miyasaka, K. Tanemura, K. Nakajima, and K. Takagi, Tetrahedron, 62, 9872 (2006).

29. Y. Nishihara, Y. Inoue, Y. Nakayama, T. Shiono, and K. Takagi, Macromolecules, 39, 7458 (2006).

30. a) J. A. Love, J. P. Morgan, T. M. Trnka, and R. H. Grubbs, Angew. Chem., Int. Ed., 41, 4035 (2002).

b) T.-L. Choi and R. H. Grubbs, Angew. Chem., Int. Ed., 42, 1743 (2003).

31. For ROMP with other fast-initiating catalysts, see: U. Frenzel, T. Weskamp, F. J. Kohl, W. C. Schattenmann, O. Nuyken, and W. A. Herrmann, J. Organomet. Chem., 586, 263 (1999).

32. M. E. Childs and W. P. Weber, J. Org. Chem., 41, 3486 (1976).

33. M. Ungerank, B. Winkler, E. Eder, and F. Stelzer, Macromol. Chem. Phys., 196, 3623 (1995).

34. S. Matsumoto, K. Komatsu, and K. Igarashi, ACS Symposium Series No. 59, American Chemical Society, 1977, p. 303.

35 . a) A. D. Benedicto, B. M. Novak, and R. H. Grubbs, Macromolecules, 25, 5893 (1992).

b) M. Ungerank, B. Winkler, E. Eder, and F. Stelzer, Macromol. Chem. Phys., 198, 1391 (1997). 